it commenced at the anterior and superior part of the womb, and behind the internal mucous coat, for there was the centre of attachment, of the size of the spread hand, more intinately comnected with the tissue of the uterus, as we would say in osteology by suture harmonia. In its progress of growth the tunnor must have pushed the mucous coat before it, as an intestinal hernia does the peritoneum.

It does not appear that there could have been any discharge from the borly of the tumor (unless by transudation), as there was not any appearance of vessels opening through the mucous mombrane in front of the tumor. Whence, then, the occasional hemorrhage and periodical returns, if not from the mucous cont aforesaid ? and did it not, on the surface reflected over the lower end of the tumor, continue to perform its function as in its natural position? The mucous surface was of a deep red, and very vascular, congrested and slightly rugose.

'The alsove case may be worth consideration in a physiological as well as pathological view.

Weight of tumor, with the uterus and its immediate appendages, 173 pounds.

Farmington, Me., May, 1845. Yours respectfully, Lafayette Pemkins.

\title{
MORTIFICATION OF THE GUMS.
}

[Communicited for the Buston Medical and surgicul Jourmal.]

J. W., a boy agred 13, was attacked with influenzal in March last, from which he partially recovered. After indulging freely in animal food, he was suddenly attacked with gastro-enteritis on the $22 \mathrm{~d}$ of April. The pulse 100 and hard; the skin dry and hot; the tongue dry, furred and red. He had constant nausea and occasional vomiting. Tho bowels were slightly tympanitic and tender on pressure; they were easily moved, and the evacuations were large and watery. Occasionally diarrhœa, with tenesmus. He had paroxysms of fever in the afternoon. I adopted the plan of treatment recommended by Dr. Williams, in the October No. of this Journal. I bled him once, put him into the warm bath several times, applied warm emollient cataplasms and a blister to the bowels. His bowels were moved daily with about two grains of calomel, followed by a teaspoonfiul of castor oil when necessary. I used starch water injections daily, with or without laudanum, pro re nata. His diet was cracker water and thin gruel. Under this treatment the nausen and vomiting censed, the bowels became ensy, the pulse softened and the fever abated, the strength of the patient increased from day to day, and we indulged the hope that our little patient would soon be restored to health. Our anticipations were but too soon disappointed. On Friday evening, May 9th, we discovered that mortification had commenced under his tongue, near the third molar tooth, on the left side; it extended around all the molar teeth of that side, embracing the gum and a portion of the cheek. The cheek was slightly swollen, and the left eye was opened with some difficulty. I applied the remedies recommended by Dr. 
Dunglison in the Cychopedia of Practical Medicine : nitric acid in its offecinal strength, nitrate of silver in substance and in strong solution. The remedies seemed to check the enlargenent of the diseased surfice, but new spots appeared in other parts of the mouth; the swelling on the check continued to increase, and put on a white, shining appearance. 'The mortification continued to spread until Monday forenoon, when a lark spot appeared on the outside of the eheek. The patient died Monday forenoon.

T'he patient dug out a piece of a tooth with a knife a few days before the mortification commenced, at the place where it begum.

My patient took, as near as I can judge, twenty grains of calomel during the first week of his disease, and none afterwards. The glands were not affected, and the mouth, when the mortification commenced, presented a healthy appealance. 'This was not inflammation ending in mortification, but it was mortification without any apparent cause.

Was mortification caused by the calomel in this case? Will calomel ever cause mortification in the mouth ?

I should be gratifed to hear what the views of the profession are with regard to the probable cause of mortification in this case.
Patten, Me., May 15, 1845.
Luthir Rogers.

THE BOSTON MEDICAL AND SURGICAI, JOURNAI.

BOSTON, MAY $2 S, 1845$.

Mfedical Anniversary.-The Fellows of the Massachusetts Medical Socicty meet at the Masonic 'Temple, Tremont street, at 10 o'clock, this morning. After transacting the ordinary business, and electing Counsellors for the ensuing year, a public discourse will be given, it 1 o'clock, by Dr. W. J. Walker. After that, the members and invited grucsts will dine together. 'To-morrow the new Council hold a session at the Society's rooms in the 'Temple, to elect a President, Vice President, Secretaries, \&c. A synopsis of the doings will appear next week. This annual festival is anticipated with feclings of peculiar pleasure by the profession in Massachusetts.

Treatment of Smallpor. - " Dr. Cox, through the medium of the Cincimnati Gitzette, calls the attention of the medical profession to the subject of smallpox, and states, as the effect of an extensive experience which he has had of its treatment in its rarions modifications, that it maly not only be abbreviated in the time it has usually taken to run its course of incipient, cruptive, suppurative and desquamative fevers, but that the suppuration may be arrested, and all the swelling of the extremities prevented by the timcly application of chloride of lime. The doctor says that hy following the proposed remedy, the pitting and scarring of at great ming pretty faces mily be prevented-many valuable lires sared-ind this dis- 